\title{
PERAN GANDA ISTRI PETANI (Studi Kasus di Desa Perangian Kecamatan Baraka Kabupaten Enrekang)
}

\author{
MULTIPLE ROLES FARMER'S WIFE (Case Study in Perangian village of Baraka sub district in \\ Enrekang district)
}

\section{SUPARMAN}

Email: suparmanpps25@gmail.com

\section{Pendidikan Luar Sekolah, STKIP Muhammadiyah Enrekang, Indonesia}

\begin{tabular}{ll}
\hline Keyword & Abstract \\
Istri Petani, & Perempuan di desa perangian bekerja sebagai tenaga kerja domestik tidak \\
Peran Ganda. & mendatangkan hasil secara langsung seperti menjaga anak, Dipihak lain sesuai \\
dengan perkembangan masyarakat khususnya pada bidang ekonomi, Nampak \\
dengan nyata peran Perempuan sebagai tenaga dibidang pencari nafkah yang \\
mendatangkan hasil secara langsung. Hasil penelitian menunjukkan bahwa \\
penyebab perempuan buruh tani melakukan peran ganda adalah faktor intern yaitu \\
pendapatan suami tidak mencukupi kebutuhan hidup sehari hari, ditambah dengan \\
pengeluaran dan jumlah tanggungan dalam keluarga, faktor ekstern yaitu \\
lingkungan sekitar yang berupa lahan pertanian yang banyak membutuhkan tenaga \\
buruh tani, pendidikan yang rendah tidak memiliki keterampilan yang memadai \\
sehingga tidak ada peluang untuk kerja lainya. Bentuk peran ganda yaitu sebagai \\
Ibu, merawat anak dan suami, sebagai istri, mendidik anak dan ekonomi. Dampak \\
peran ganda bagi keluarga yaitu kesulitan dalam menjalankan tugas domestiknya, \\
kurang optimalnya waktu yang dimiliki untuk membagi peran yang dijalankan, \\
Kelelahan beraktivitas dalam pekerjaannya secara profesional, dan terjadi \\
pengeluhan dirasakan oleh istri terhadap suami ketika mereka sudah lelah dalam \\
bekerja.
\end{tabular}




\section{PENDAHULUAN}

Kedudukan dan peranan perempuan-perempuan di Indonesia telah tampak sejak zaman kerajaan sampai sekarang ini. Peranan perempuan Indonesia cukup beragam disebabkan oleh perbedaan tingkat peradaban kebudayaan berbagai suku bangsa dan pola-pola kehidupan masyarakat. Secara hukum perempuan di Indonesia berpeluang sama dengan laki-laki untuk berprestasi sesuai dengan potensinya dalam proses pembangunan.ditegaskan dalam UUD 1945 (pasal 27) mengenai kesamaan hak dan kewajiban bagi penduduk, tanpa membedakan laki-laki dan perempuan seperti dibidang kesehatan, hak perempuan, hukum, politik dan pekerjaan.

Meningkatnya keterlibatan perempuan dalam kegiatan ekonomi ditandai dengan meningkatnya jumlah perempuan yang terlihat dalam pekerjaan diluar rumah tangga (outdoor activities). Hal ini, dapat dilihat dari kenaikan tingkat partisipasi perempuan dari waktu ke waktu. Peningkatan dalam jumlah bidang pekerjaan yang dapat dimasuki perempuan dimana sebelumnya bidangbidang tersebut masih didominasi oleh laki-laki berangsur-angsur dimasuki atau bahkan mulai didominasi oleh perempuan. Keterlibatan perempuan dalam berbagai bidang pekerjaan menjadi gejala yang mencolok tahun 1980-an. Abdullah dalam Wahidah (2008)

Istri petani ternyata memiliki peranan yang penting dalam menyiasati serta mengatasi kemiskinan yang dialaminya. Masyarakat di desa Perangian Kecamatan Baraka Kabupaten Enrekang adalah salah satu bukti nyata yang ada di dalam masyarakat mengenai peranan kaum perempuan pada masyarakat petani dalam upaya meningkatkan kesejahteraan rumah tangga. Sebagai salah satu desa yang terletak jauh dari keramaian Kota Enrekang, mata pencaharian masyarakat desa Perangian adalah sebagian sebagai petani. Sebagian besar perpotensi sebagai pemilik lahan dan pekerja.

\section{TINJAUAN PUSTAKA}

1. Masyarakat

Masyarakat adalah kesatuan hidup manusia yang berinteraksi sesuai dengan system adat-istiadat tertentu yang sifatnya berkesinambungan. Begitu juga masyarakat yang ada di desa perangian memiliki hubungan yang sangat kuat, gotong royong, kerja sama dan ikatan kekelurgaan yang masih sangat kental, dalam kegiatan sehari hari yang dilakukan oleh masyarakat desa perangian adalah kegitan pertanian karna lahan di desa perangian sangat cocok untuk kegiatan pertanian.

\section{Keluarga}

Keluarga merupakan suatu
lembaga sosial dasar dimana semua lembaga atau pranata sosial lainnya berkembang. Keluarga adalah unit terkecil dari masyarakat yang terdiri atas kepala keluarga dan beberapa orang yang terkumpul dan tinggal di suatu tempat dibawah suatu atap dalam keadaan saling ketergantungan. Yang di dalamnya terdapat interaksi hubungan sosial antar keluarga (suami, istri dan anak-anak) dan yang saling membutuhkan maupun mempengaruhi antara yang satu dengan yang lain, di dalam keluarga lah karakteristik diri itu akan terbentuk menjadi sebuah kpribadian. Keluarga merupakan tempat dimana semua anggota (suami, istri, anak-anak) 
berkumpul untuk berbagi cerita suka maupun duka, suatu wadah tumpuhan untuk melepas lelah dari semua aktifitas yang telah dikerjakan diluar rumah dan sebagai tempat peristirahatan untuk melepas kepenatan dari kesibukan kerja baik dikantor maupun dipabrik yang telah dilakukan seharian diluar rumah. Setiap anggota keluarga memiliki tanggung jawab masing-masing dan saling memperkuat hubungan satu sama lain di dalam keluarga tersebut demi keutuhan dan keharmonisan keluarga.

\section{Peran ganda istri}

Peran ganda merupakan dua peran yang dijalankan oleh seorang saja dalam menjalankan suatu tugas yang memang sudah menjadi hal yang dikerjakannya (bekerja) dan juga salah satu peran itu telah menjadi kodrat yang memang telah melekat dari dahulu pada diri dan tanggung jawabnya (ibu rumah tangga) di dalam sebuah keluarga. Dalam keluarga konvensional, suami bertugas mencari nafkah dan istri yang mengurus rumah tangga. Tetapi kini, dengan tumbuhnya kesempatan bagi Perempuan bersuami untuk bekerja, pada pola kekeluargaan segera berubah dan muncul apa yang disebut sebagai dualisme karir. Dualisme (persamaan karir) karir terjadi bila suami maupun istri sama-sama bekerja dan mengurus rumah tangga secara bersama pula. Di dalam hubungannya dengan posisi masing-masing, setiap pasangan suami istri memiliki cara yang berbeda di dalam mengatur peranannya dalam pekerjaan dan rumah tangga. Perempuan yang bekerja secara part time umumnya menganggap bahwa pekerjaan hanyalah sekedar hobbi dan hanya menduduki prioritas kedua dibawah kepentingan keluarga. Tetapi dalam keluarga dualisme karir egalitarian, suami istri bekerja tidak hanya sekedar mencari nafkah tetapi juga dalam persaingan untuk mendapatkan posisi yang sama dalam pengambilan keputusan serta berbagai aktivitas dalam keluarga.

\section{Peranan Perempuan Dalam Kesejahteraan Rumah Tangga}

Arti peran disni sudah jelas bahwasannya seorang yang memiliki tugas yang sudah menjadi kewajibannya untuk dijalankan yang sesuai dengan perannya, namun ada pula seorang yang menjalankan dua peran sekaligus walaupun itu sebenarnya bukan kewajibannya. Peran ganda yang seperti ini juga dijalankan oleh seorang Perempuan yang sudah menikah dan memiliki suami, di dalam keluarganya dia memiliki peran ganda sebagai seorang istri atau ibu untuk suami sekaligus anakanaknya(ibu rumah tangga) dan juga sebagai seorang pekerja mencari nafkah tambahan (Perempuan karir) berbagai macam pekerjaan dijalankannya untuk membantu suaminya mencari nafkah tambahan untuk memenuhi kebutuhan domestik keluarga maupun kebutuhan material yang dibutuhkan dalam keluarga.

\section{Landasan Teori}

Adapun teori teori yang membahas mengenai peran ganda istri petani:

\section{a. Teori Feminisme liberal}

Konsep liberal tentang hakikat manusia yang mengatakan bahwa yang membedakan manusia dari binatang adalah kemampuan yang dimiliki oleh manusia, seperti rasionalitas, yang mempunyai 2 aspek yaitu moralitas pembuat keputusan yang otonom - dan prudentialitas - pemenuh kebutuhan diri sendiri. Manusia, Perempuan dan pria, diciptakan sama dan mempunyai hak yang sama, dan harus pula mempunyai kesempatan yang sama untuk memajukan dirinya. Asumsi dasar Feminisme liberal 
adalah bahwa kebebasan (freedom) dan kesamaaan (equality) berakar pada rasionalitas dan pemisahan antara dunia privat dan publik. Dalam memperjuangkan persoalan masyarakat, menurut kerangka kerja feminis liberal, tertuju pada "kesempatan yang sama dan hak yang sama" bagi setiap individu, termasuk di dalamnya kaum perempuan. Kesempatan dan hak yang sama antara laki-laki dan perempuan ini penting, sehingga tidak perlu pembedaan kesempatan

\section{b. Teori Fungsionalisme Struktural}

Oleh peneliti yang mengenai peran ganda istri dalam keluarga di kaji dengan teori fungsinalisme structural ini yakni setiap peran dari peran ganda istri ini memilki fungsi yang berkaitan dengan fungsi yang lainnya, baik pada istri maupun pada suami. Bila dilihat fungsi manifesnya yakni: peran ganda istri dapat membantu suami dalam membangun perekonomian keluarga sedangkan fungsi latennya yakni: ditakutkan terjadinya ketidak adilan dalam pencarian perekonomian dan terbengkalainya peran istri sebagai ibu rumah tangga dalam hal domestik.

\section{METODE PENELITIAN}

Jenis penelitian yang digunakan peneliti adalah penelitian kualitatif. Adapun pendekatan yang digunakan dalam penelitian ini adalah pendekatan Studi kasus (case study), Studi kasus (case study) merupakan suatu penelitian yang dilakukan terhadap satu kesatuan sistem. Kesatuan ini dapat berupa program, kegiatan, peristiwa, atau sekelompok individu yang terikat oleh tempat, atau ikatan tertentu. Studi kasus ini merupakan metode untuk menghimpun dan menganalisis data berkenaan dengan sesuatu kasus. (Sukmadinata, 2009: 7778).

Penelitian ini dilakukan di desa perangian yang difokuskan pada faktor, bentuk dan dampak peran ganda yang dilakukan oleh istri petani. Penentuan informan mengguanakan teknik purposive sampling (pengambilan data secara sengaja berdasarkan karakteristik yaitu umur, tingkat pendidikan, pembagian kerja dan penghasilanya). Informan yang di maksud adalah : (1) perempuan yang menjadi buruh tani terdiri dari 10 orang (2) suami dari istri yang menjadi buruh tani terdiri dari 2 oarang (3) pemerintah setempat yaitu kepala desa perangian (4) tokoh masyarakat dan agama. untuk mempermudah peneliti maka perlu sekiranya mengklasifikasikan informan yang ada. Adapun Tehnik pengumpulan data yang digunakan dalam penelitian ini adalah (1) Observasi, (2) Wawancara, dan (3) Dokumentasi.

\section{HASIL PENELITIAN DAN PEMBAHASAN}

\subsection{Hasil Penelitain}

a. Kasus I : ibu Idak

Pendidikan terakhir Idak adalah sekolah dasar (SD), Sehari-hari Ibu Idak bekerja sebagai buruh tani di desa perangian, Ibu Idak mulai mempersiapkan diri dari jam 5 subuh untuk menjalankan aktivitas domestik setelah itu kemudian berangkat ke kebun untuk jadi buruh tani mulai dari jam 07.30 sampai 16.00 wita . pendapatan yang diperoleh Ibu Idak adalah $\mathrm{Rp}$ 60.000,-/hari. Pendapatan ini menurut Ibu Idak cukup menjadi perekonomian rumah tangganya mereka sudah mampu membiayai kehidupan keluarganya yang sudah bisa dibilang udah senja, mulai dari kebutuhan seharihari, membayar listrik dan tambahan biaya pengobatan untuk suaminya yang 
sedang sakit. Ibu Idak menjadi buruh tani karena suaminya akhir-akhir ini sakit stroke ringan, kmudian dia juga tidak mau menggantungkan drinya kepada anakanaknya katanya aku masih sanggup untuk mencari makan sendiri dan memenuhi kebutuhan kelarga, Ikut sertanya Ibu Idak bekerja untuk menambah perekonomian keluarga berarti ia harus siap menjalankan peran ganda, peran sebagai lbu rumah tangga dan sebagai pencari pendapatan tambahan bagi rumah tangganya, alokasi yang dibutuhkan Ibu Idak untuk pekerjaan produktifnya sekitar 8 jam.

\section{b. Kasus II : ibu Mida}

$$
\text { Ibu Mida, (47 tahun) hanya }
$$
mengecap pendidikan sampai sekolah dasar (SD), Sehari-hari Ibu Mida bekerja sebagai buruh tani di desa perangian, lbu Mida mulai mempersiapkan diri dari jam 5 subuh untuk menjalankan aktivitas domestik mulai dari kegiatan membersihkan rumah, memasak mencuci dan mempersiapkan kebutuhan sekolah anaknya, setelah itu kemudian berangkat ke kebun untuk jadi buruh tani mulai dari jam 07.30 sampai 16.00 wita, Suami Ibu Mida bernama Mendak (52 tahun) dan hanya tamatan sekolah dasar (SD) bekerja sebagai petani dan kadangkala juga sebagi buruh tani kalau tidak ada lagi yang dikerjakan di kebun sendiri dan pengahasilanya sangat tidak menentu kadangkala ada untung kadangkala juga rugi dalam bertani, Pasangan Mendak dan Mida memilikii 3 orang anak, yang masing masing anak masih sangat membutuhkan biaya yang tinggi. Anak pertama bernama misran sudah di jenjang perkuliahan meskipun dibiayai oleh tantenya di kota pare-pare tapi mengenai kebutuhan seperti pakaian, dan peralatan kampusnya masih dibiayai oleh Ibu Mida, anak kedua bernama Adi ditingkat SMA dan anak ke tiga bernama rani dibangku SD yang masing-masing sangat membutuhkan biaya yang tidak sedikit, Biaya/pengeluran Ibu Mida setiap bulanya yaitu: biaya kebutuhan makan sehari-hari, biaya listrik, biaya sekolah anak dan biaya lain yang tak terduga.

c. Kasus III: ibu Mili

Ibu Mili, (36 tahun) hanya mengecap pendidikan sampai sekolah dasar (SD). la tidak melanjutkan kejenjang berikut karna masalah biay, Sehari-hari Ibu Mili bekerja sebagagai penjual oalahan makanan kue dan bakso, ia mulai bagun untuk membuat kue sekitar jam 3 pagi untuk mengejar target penjualan karna di desa peragian orang sangat pagi-pagi sekali untuk ke kebun makanya Ibu Mili harus bagun pagi-pagi. Ibu Mili mengerjakan dari membuat adonan, membentuk adonan, menggoreng dan menjual.pendapatan yng diperoleh Ibu Mili adalah Rp 2,000.000/ bulan. Pendapatan ini sangat membantu dalam perekonomian rumah tangganya dan biaya sekolah anak-anaknya. Alokasi waktu yang ia butuhkan untuk membuat adonan sampai menjualnya sekitar 4-5 jam, Pasangan budik dan Mili memilikii 3 orang anak, yang masing masing anak masih sangat membutuhkan biaya yang banyak, anak pertama bernama pirman masih duduk dibangku sekolah menegah atas (SMA), jarak antara rumah dan sekolah hampir $15 \mathrm{KM}$ jadi harus menggunakan kendaran, anak yang kedua bernama asis masih duduk dibangku sekolah dasar (SD) dan anak yang kitiga bernama perdi yang duduk juga di bangku sekolah dasar (SD), Biaya/pengeluran Ibu Mili setiap bulanya yaitu: biaya kebutuhan makan sehari-hari, biaya listrik, biaya sekolah anak dan biaya lain yang tak terduga. 


\section{d. Kasus iv: ibu Tati}

Sehari-hari Ibu tati bekerja sebagai buruh tani di desa perangian, Ibu tati mulai mempersiapkan diri dari jam 5 subuh untuk menjalankan aktivitas domestik mulai dari kegiatan membersihkan rumah, memasak dan mencuci, setelah itu kemudian berangkat ke kebun untuk jadi buruh tani mulai dari jam 07.30 sampai 16.00 wita . pendapatan yang diperoleh Ibu tati adalah $\mathrm{Rp} 60.000$,/hari. Pendapatan ini menurut Ibu tati cukup membantu menjadi perekonomian rumah tangganya mereka sudah mampu membantu membiayai kehidupan keluarganya. Ibu tati menjadi buruh tani karena merasa bahwa bahwa daripada bermalas-malasan dirumah mending membantu suami dalam memenuhi kebutuhan rumah tangga, ikut sertanya Ibu Tati bekerja untuk menambah perekonomian kelurga berarti ia harus siap menjalankan peran ganda, peran sebagai Ibu rumah tangga dan sebagai pencari pendapatan tambahan bagi rumah tangganya, alokasi yang dibutuhkan Ibu tati untuk pekerjaan produktifnya sekitar 8 jam, Menjalankan peran sebagai pengurus rumah tangga dan sebagai pencari nafkah tambahan, Ibu tati menjalankan perananya sebagai buruh tani karna merasa bosan di rumah tapi menurut Ibu tati tidaklah mudah. Pekerjaan rumah tangga dikerjakan oleh tati sendiri tampa ada bantuan dari suaminya. Aktivitas sosial yang dilakukan oleh Ibu tati dilingkungan sekitar dengan ikut membantu kalau ada hajatan tetangga.

\section{e. Kasus v: ibu Jumriyah}

Ibu Jumriyah, (24 tahun) pendidikan sampai sekolah menegah ata (SMA). la tidak melanjutkan kejenjang berikut karna masalah biaya, Sehari-hari Ibu Jumriyah bekerja sebagai buruh tani di desa perangian, Ibu Jumriyah belum lama menikah karna memang waktu sebelum menikah lbu Jumriyah sering menjadi buruh tani untuk memenuhi kebutuhanya sendiri, Ibu Jumriyah mulai mempersiapkan diri dari jam 6 pagi untuk menjalankan aktivitas domestik yaitu kegiatan memasak, setelah itu kemudian berangkat ke kebun untuk jadi buruh tani mulai dari jam 07.30 sampai 16.00 wita . pendapatan yang diperoleh Ibu Jumriyah adalah Rp 60.000,-/hari. Pendapatan ini menurut Ibu Jumriyah cukup membantu perekonomian rumah tangganya apalagi kebutuhan saya sendiri seperti perlengkapan make up saya, Menjalankan peran sebagai pengurus rumah tangga dan sebagai pencari nafkah tambahan, menurut jumriyah tidaklah mudah, tetapi ia harus menjalaninya ia agar dapat membantu suaminya untuk memenuhi kebutuhan rumah tangganya. Pekerjaan rumah tangga dikerjakan oleh jumriyah sendiri. Aktivitas sosial yang dilakukan oleh jumriyah dilingkungan sekitar dengan ikut membantu kalau ada hajatan tetangga.

\subsection{Pembahasan}

\section{Factor intern}

\section{a. Pendapatan/ penghasilan}

Fakta yang banyak terjadi saat ini istri dituntut untuk dapat berpartisipasi untuk memenuhi kebutuhan hidup yang semakin tinggi terlebih lagi ketika pendapatan diperoleh sang suami tidak dapat mencukupi kebutuhan hidup sehari hari, maka secara otomatis peran istri untuk menunjang perekonomian keluarga sangat diperlukan. Keadaan ini banyak terjadi pada keluarga ekonomi rendah dimana penghasilan dari sang suami sangat kecil, sehingga tidak mungkin untuk mencukupi pemenuhan kebutuhan hidupsehari hari. Rumah tangga ibu buruh tani tergolong rumah tangga ekonomi rendah kebawah. Hal tersebut karena 
penghasilan dari sang suami tidak mencukupi kebutuhan hidup rumah tangga, hal ini diperpuruk pula dengan naiknya harga-harga barang sehingga keadaan seperti ini sangat sulit bagi ibuibu buruh tani dalam pemenuhan kebutuhan sehari-hari. Lemahnya perekonomian pada akhinya menuntut peran dari seorang istri dalam upanya untuk memenuhi kebutuhan hidup rumah tangga yang selanjutnya akan meningkatkan kesejahtraan rumah tangganya.

\section{b. Biaya/ pengeluaran rumah tangga}

Biaya rumah tangga yaitu untuk pemenuhan kebutuhan primer, pangan dan sandang. Sedangkan untuk kebutuhan sekunder adalah untuk kebutuhan pendidikan anak, kebutuhan social berupa berbagai iuran atau sumbangan. Banyaknya biaya rumah tangga mempengaruhipendapatan yang telah dihasilkan sehingga jika pengeluaran cukup banyak maka hal ini membuat ibuibu berusaha mencari tambahan untuk memenuhi kebutuhan hidup dalam rumah tangga.

\section{c. Jumlah tanggungan}

\section{Jumlah tanggungan keluarga} mempengaruhi juga pengeluaran kelurga. Artinya semakin banyak jumlah anggota kelurga, semakin banyak tanggnganya maka semakin banyak pula biaya hidup yang dibutuhkan.jumlah tanggungan kelurga merupakan banyaknya angota kelurga yang tidak produktif dan produktif, baik yang mendapatkan penghasilan maupun yang tidak mendapatkan penghasilan dan secara ekonomis masih menjadi tanggung jawab kelurga.

\section{Factor ekstern}

Faktor yang menyebabkan para ibu buruh tani melakukan propesi ini karena lingkungan di desa perangian yang mereupakan lahan pertanian yang cukup luas sehingga banyak permintaan untuk menjadi buru tani, mereka para ibu buruh tani tidak memeiliki pendidikan yang tinggi dan keterampilan yang memadai sehingga tidak ada peluang kerja yang lain yang membuat mereka melakukan pekerjaan sebagai buruh tani yang hanya mengandalkan kekuatan otot dan tenaga. Umumnya pendidikan terakhir mereka adal sekolah dasar dan sekolah menegah pertama, mereka tidak melanjutkan kejenjang berikutnya karena tersandung oleh maslah biaya sekolah.

\section{a. Bentuk peran ganda istri}

\section{Peran sebagai ibu}

Sebagai seorang wanita yang sudah menikah, menjadi seorang Ibu adalah salah satu tugasnya yaitu menyayangi dan memperhatikan anak adalah kewajiban untuknya, meskipun waktu tidak sepenuhnya diberikan kepada anak seperti istri-istri yang telah di teliti oleh peneliti. Mereka tidak begitu banyak memilikii waktu karena waktu mereka telah terbagi dengan pekerjaan, namun para ibu yang berperan sebagai buruh tani berupaya untuk menjadi ibu yang baik untuk anak-anaknya.

\section{Peran merawat anak dan suami}

Seorang istri yang seharusnya menjalankan kewajibannya sebagaimana tanggung jawabnya untuk merawat anak atau suami telah dijalankan oleh para istriistri yang diteliti oleh peneliti. Istri-istri merawat anak dan suaminya dengan memperhatikan semua kebutuhan, mulai dari kebutuhan makanan anak dan suami, yang memasakkan makan untuk mereka, menyiapkan bekal-bekal makanan, 
sebelum berangkat kerja semua makanan sudah harus siap. Seperti yang di kerjakan oleh Ibu Idak, Mida, Mili, Tati dan juga Ibu Jumriya beliau sebelum berangkat bekerja tetap memasakkan anak dan suaminya, sepulang kerja pun juga menyempatkan diri untuk membersihkan rumah, mengepel.

\section{Berperan sebagai istri}

Untuk peran sebagai istri, seorang istri senantiasa mendampingi suami baik dalam keadaan suaka maupun duka, selain selain mendampingi juga melayani suami. Dari hasil penelitian bahwa telah menggambarkan bagaimana seorang wanita yang menjadi istri untuk suami dengan tetap memposisikan suami pada posisinya dan tidak merendahkannya dengan perbedaan antara penghasilan yang diperolehnya dan tetap menerima suami apa adanya. Semua istri yang diteliti oleh peneliti yakni Ibu Idak, Ibu Mida, Ibu Mili, Ibu tati, dan juga Ibu jumriyah mereka semua tetap memposisikan suaminya pada posisi utamanya yakni sebagai kepala rumah tangga.

\section{Berperan dalam hal mendidik anak}

Selain berperan sebagai Ibu rumah tangga, istri juga mempunyai peran untuk mendidik anak-anak mereka agar menjadi anak yang baik dan berpendidikan. Walau sesibuk apapun istri masih menyempatkan waktu untuk mengajari anaknya belajar, membiasakan anak untuk bisa disiplin dan mandiri tanpa selalu memanjakan anak, membantu mengerjakan PR sekolah dengan mengajarinya.Seperti pada Ibu Mida, Ibu Mili, Ibu tati yang menyempatkan waktu untuk mengajari belajar anaknya. Ketika Ibu Mili menjaga toko beliau juga menyempatkan untuk mengajari anaknya belajar meski harus belajar ditoko.

\section{Berperan dalam hal ekonomi}

Untuk berperan dalam perekonomian, seorang wanita yang telah menikah yang dipanggil dengan sebutan seorang istri sekarang ini telah memilki peran yang sama seperti seorang suami yaitu bekerja, untuk menambah tingkat penghasilan ekonomi keluarganya. Selain suami yang bekerja seorang Ibu juga diberi kebebasan untuk ikut andil dalam dunia pekerjaan.Seperti para istri yang diteliti oleh peneliti, istri juga ikut serta dalam menambah tingkat perekonomian keluarga. Ibu Idak, Ibu Mida, Ibu tati, Ibu jumriyah mereka ikut andil bekerja sebagai buruh tani, sedangkan Ibu Mili beliau memilki usaha dengan membuka toko dirumahnya sendiri.

b. Dampak bagi kelurga peran ganda

\section{Beban kerja}

Sebagaimana hasil penelitian ditemukan adanya kecendrungan pada kasus perempuan beban kerja meningkat sebagai konsekwensi dari peran gandanya. Namun dengan kemampuanya mengadaptasikan diri dengan lingkungan yang dimiliki secara lambat laun berjalan dengan seimbang antara beban tugas pekerjaan domestic dengan tugas pekerjaan public sebagai wilayah pekerjaan yang produktif. Demikian apa yang ditemukan dari hasil wawancara dari subjek penelitian sebagaimana yang dituturkan yang intinya mengakui adanya beban pekerjaan pada saat anak mereka bertambah.

\section{Kesulitan dalam pekerjaan domestik}

Mereka sedikit kesulitan dalam menjalankan tugas domestiknya karena kurang optimalnya waktu yang dimiliki untuk membagi peran yang dijalankan, seperti pada Ibu Mida dalam hal merawat anak mereka, rasa kepikiran terhadap anak karena kurang begitu optimal dalam 
merawat anak-anak mereka, rasa kurang merawat seperti dalam hal mengajari anak ketika belajar, karena waktu untuk mendidik anak-anak kurang begitu optimal.

\section{Kelelahan beraktivitas}

Kelelahan beraktivitas dalam pekerjaannya yang secara profesional, yang mengakibatkan rasa emosi yang kurang stabil muncul karena terlalu kelelahan dalam pekerjaan yang bias mengakibatkan sedikit menggangu kondisi keluarga, karena waktu dengan keluarga hanya sedikit dan waktunya lebih banyak digunakan untuk bekerja.

\section{Pengeluhan oleh istri}

Terjadi pengeluhan yang dirasakan oleh istri terhadap suami ketika mereka sudah lelah dalam bekerja, suaminya tidak mau membantunya karena ada pula suami yang sedikit pasif dalam hal domestik seperti pada suami lbu Tanti yang pasif dalam hal Domestik, yang tidak begitu aktif membantu istrinya dalam menyelesaikan pekerjaan rumah.

\section{PENUTUP}

\subsection{Kesimpulan}

Dari hasil analisa dari pembahasan pada bab-bab sebelumnya yang dilakukan dalam penelitian ini, maka dapat diperoleh kesimpulan sebagai berikut:

1. Penyebab perempuan buruh tani melakukan peran ganda adalah faktor intern yaitu pendapatan suami tidak mencukupi kebutuhan hidup sehari hari, ditambah dengan pengeluaran dan jumlah tanggungan dalam keluarga, faktor ekstern yaitu lingkungan sekitar yang berupa lahan pertanian yang banyak membutuhkan tenaga buruh tani, pendidikan yang rendah tidak memiliki keterampilan yang memadai sehingga tidak ada peluang untuk kerja lainya.

2. Bentuk peran ganda yaitu sebagai Ibu, merawat anak dan suami, sebagai istri, mendidik anak dan ekonomi.

3. Dampak peran ganda bagi keluarga yaitu kesulitan dalam menjalankan tugas domestiknya, kurang optimalnya waktu yang dimiliki untuk membagi peran yang dijalankan, Kelelahan beraktivitas dalam pekerjaannya secara profesional, dan terjadi pengeluhan dirasakan oleh istri terhadap suami ketika mereka sudah lelah dalam bekerja.

\subsection{Saran}

Berdasarkan hasil penelitian yang penulis lakukan, ada beberapa hal yang hendak perlu dibenahi. Beberapa saran yang bisa peneliti berikan yakni :

1. Disarankan kepada pemerintah Kota Enrekang terkusus di Kacamatan Baraka agar memperhatikan kondisi Desa perangian terutama dalam segi kesehatan, dan kesejahtraan masyarakat. Dengan memberikan pelatihan dan keterampilan yang baik dan tepat meningkatkan kesejahtraan dan kualitas mutu kesejahtraan nasional.

2. Kepada istri yang berperan ganda agar bisa membagi waktu untuk suami dan anaknya, karena selain pekerjaan anak dan suami juga penting untuk diperhatikan agar tetap terjalin hubungan keluarga yang harmonis dan seimbang.

3. Kepada suami yang pasif tidak mau mengerti dan tidak mau membantu istrinya agar tidak hanya mengandalkan istri maupun meremehkan terhadap istri yang telah ikhlas membantu mencari nafkah.

4. Kepada Peneliti yang selanjutnya, peniliti berharap kepada peneliti berikutnya untuk bisa melanjutkan 
penelitian lanjutan dalam perspektif yang berbeda.

\section{DAFTAR PUSTAKA}

[1] Abdullah, Irwan. 997. Sangkan Paran Gender, Yogyakarta: Pusat Penelitian Kependudukan UGM, Pustaka Tama Pelajar.

[2] Arikonto, S. 2010. Prosedur Penelitian: Suatu Pendekatan Praktik. Jakarta: Rineka Cipta.

[3] Arif Mukhrisal, Dkk. 2014. Pendidikan Posmodernisme. Yogyakarta: Ar-Ruzz Media.

[4] Arikunto. 1998. Prosedur Penelitian (Suatu Pendekatan Praktek). Jakarta: PT. Reneka Cipta.

[5] Budiman, Arief. 1998. Pembagian Kerja Secara Seksual. Jakarta : Gramedia.

[6] Bungin, B. 2007. Penelitian kualitatif: komunikasi, Ekonomi, kebijakan Publik, dan IImu Sosial Lainnya. Jakarta: Prenada Media Group.

[7] Cleves Mosse, Julia. 1996. Gender dan Pembangunan, Yogyakarta: Pustaka Pelajar.

[8] Fakih Mansour. 1996. Analisis Gender dan Transformasi Sosial. Yogyakarta: Pustaka Pelajar.

[9] Foucault. 1997. Seks dan Kekuasaan.Terjemahan oleh Rahayu S Hidayat. Jakarta: Gramedia.

[10] Goode, William J. 2007. Sosiologi Keluarga. Jakarta: PT. Bumi Aksara.

[11] Hariwijaya \& Triton. 2007. Pedoman Proposal dan Skripsi. Yogyakarta: Oriza.

[12] Ihromi, T.O. 1995. Kajian Wanita Dalam Pembangunan. Jakarta: Yayasan Obor Indonesia.

[13] Itsna Sugihastuti. 2007. Gender dan Inferioritas Perempuan. Yogyakarta: Pustaka Pelajar

[14] Latief M.Ali. 2010. Peran ganda perempuan (studi pada lima perempuan berkeluarga bekerja sebagai pegawai negeri sipil di kota makassar). Disertasi. Tidak diterbitkan. Makassar: Program Pascasarjana UNM Makassar.

[15] Katjasung Kanah, Nur Syahdi. 2001. Potret Perempuan Tinjauan Politik Ekonomi dan Hukum di Zaman Orde Baru, Yogyakarta: Pustaka Pelajar.

[16] Kartini. 2007. peran perempuan pada industry rumah tangga pembuatan tempe dan tahu dikacamatan mamajang kota Makassar. Tesis. Tidak diterbitkan. Makassar: Program Pascasarjana UNM Makassar.

[17] Musdalifah.A. 2010. peran ganda perempuan dalam rumah tangga studi kasus ibu tukang cuci dikmpung parang kecamatan tamanlanrea kota Makassar. Tesis. Tidak diterbitkan. Makassar: Program Pascasarjana UNM Makassar.

[18] Mufidah. 2004. Paradigma Gender, Malang: Bayumedia.

[19] Ollen Burger, Jane C \&Hellen A Moore. 1996. Sosiologi Wanita. Jakarta : Rineke Cipta.

[20] Piliang, Amir Yasraf. 2004. Dunia yang Dilipat. Jogjakarta : Jalasutra.

[21] Raditya, Ardhie. 2014. Sosiologi Tubuh, Membentang Teori di Ranah Aplikasi. Yogyakarta : Kaukaba.

[22] Ramayulis, et.al. 1987. Pendidikan Islam Dalam Rumah Tangga, Jakarata: Kalam Mulia.

[23] Ritzer, George. 2009. Sosiologi IImu Pengetahuan Berparadigma Ganda, Jakarta: Pt. Raja Grafindo Persada.

[24] Ritzer, George. 2012. (cet.1), Teori Sosiologi Dari Sosiologi Klasik Sampai Perkembangan Terakhir Postmodern. Jogjakarta: Pustaka Pelajar.

[25] R.M Maclver \& Charles H. 1961. Society, an Introductory Analysis. London : Macmillan \& Co. 
[26] Ritonga. 1996. Fungsi Keluarga dalam Meningkatkan Kualitas Sumber Daya Manusia Daerah Sumatera. Medan: Departemen Pendidikan dan Kebudayaan Republik Indonesia.

[27] Said Abdullah. 2014. Peran Ganda Istri Komunitas Petani Padi Di Desa Laro Kecamatan Burau Kabupaten Luwu Timur. Skripsi. Tidak diterbitkan. Makassar: Universitas Muhammadiyah Makassar.

[28] Salim, Agus. 2001. Teori dan Paradigma Penelitian Sosial. Yogyakarta: Tiara Wacana.

[29] Sajogyo, pudjiwati, Peranan Wanita dalam Perkembangan Masyarakat Desa, Rajawali, 1985, Jakarta.

[30] Singarimbun, M. 1982. Metode Penelitian Survei. Jakarta: LP3ES.

[31] Sugiyono. 2012. Metodologi Penelitian Kuantitatif Kualitatif dan $R \& D$. Alfabetha: Bandung
[32] Suyanto, Bagong \& Dwi Narwoko. 2007. Sosiologi Teks Pengantar dan Terapan. Jakarta: Kencana Prenada Media Pressindo.

[33] Sapari, Ratna \& Briggitte Holzner. 1997. Perempuan Kerja dan Perubahan Sosial. Jakarta: P. T Pustaka Utama Grafiti.

[34] Suhartono, Irawan. 2002 Metode Penelitian Sosial. Bandung: Remaja Rosdakarya.

[35] Suyanto, Bagong \&Sutinah. 2007. Metode Penelitian Sosial. Jakarta: Kencana Prenada Group.

[36] S Anshori, Dadang. 1997. Membincangkan Feminisme. Bandung: Pustaka Hidayah.

[37] Suyanto, B. \& Sutinah. (Eds.), 2005. Metode Penelitian Sosial: Berbagai Alternatif Pendekatan. Jakarta: Kencana Prenada Media Group. 